https://doi.org/10.48009/2_iis_2007_57-62

\title{
Using Media and Information Systems to Explain the Eeffects of Globalization and Migration
}

\author{
Mark McGregor, S.J., Fairfield University, mmcgregor@mail.fairfield.edu \\ Winston Tellis, Fairfield University, winston@mail.fairfield.edu
}

\begin{abstract}
In this paper, the authors present the plight of a significant segment of immigrants unaccompanied minors - who are not just alone in frightening circumstances, but often need services. The authors explore the role of Information Technology (IT), Particularly the Internet in providing information to organizations who serve this population.
\end{abstract}

\section{INTRODUCTION}

In the late $20^{\text {th }}$ and early $21^{\text {st }}$ century, some consequences of global economic forces could be seen in the faces of ten million children, onefifth of nearly 50 million migrants, refugees and displaced persons across the world (1). "Millions of these children are "Out of place"; doubly displaced from family and state, in sweatshops, refugee camps, bordellos and orphanages" (2). Unaccompanied minors comprise about 500,000 of these children. The United States and many other countries have witnessed an increase of unaccompanied immigrant children (UIC). These "receiving countries" must develop an approach to deal with UIC and must work with "sending countries" as they confront many issues, including how to care for thousands of UIC and how to evaluate any legal claims these minors might find in a foreign country (2).

Lacking the rights of American citizens, these children who have human rights, are thrust into a system that was designed for adults, often without legal counsel or the emotional support of families to help them cope. Between 2004 and 2006, the U.S. Department of Homeland Security (DHS) and local law enforcement agencies apprehended more than 101,000 UIC, the vast majority of whom, DHS turned back within days of their arrest. However, DHS turned over 6,200 children in 2004 and over 7,700 children in 2005 and 2006 (3) to the Office of
Refugee Resettlement (ORR), within the Department of Health and Human Services. The

United States defines as unaccompanied minors "children under the age of 18 who seek admission to the United States and who are not accompanied by a parent or guardian” (4).

\section{Push and Pull Factors of Migration}

Trade agreements like the North American Free Trade Agreement (NAFTA) have ushered in a new phase of globalization in the Western Hemisphere in 1992, one that includes an expanded migrant labor market (5). For Mexico, NAFTA was supposed to create millions of jobs, raise wages, and diminish the lure of the north. Actually, it has made more Mexicans unemployed and increased the lure of America. More than 6.2 million Mexicans now live in the United States illegally, according to Mexico's National Council of Population: two-thirds of whom arrived after NAFTA (6). CAFTA, the subsequent agreement between the US and Central American countries, could similarly affect the fragile economies there (7). Increased migration might result, if CAFTA follows the pattern of NAFTA. According to a survey in 2005, almost $8,000,000$ of $12,000,000$ unauthorized migrants are from Mexico and Latin America, about two-thirds of whom have been in the US less than 10 years.

The unaccompanied immigrant children are overwhelmingly from Mexico and Central American countries (3). Each child has a compelling story of why she or he would seek life in the US. Many children seek reunification with family members who have come north. Some flee civil unrest, crushing poverty, life on the street, prostitution or gang violence. Some are trafficked or sent by family to earn income for their families (1). A majority of the 101,000 children apprehended between 2004 and 2006 were from Mexico, and returned voluntarily, avoiding detention. Statistics have shown that about $85 \%$ of UIC in ORR custody consistently 
came from three Central American countries: El Salvador, Guatemala, and Honduras. In 2006, Mexico, with $7 \%$, was the only other country with more than $1 \%$ of detainees. Approximately 95\% of the children placed in ORR originate from Latin America. China was the only nonLatin American country of origin to account for $1 \%$ or more of UIC already in ORR custody (3). Caring for UIC in Latin America has become a much larger issue, as was illustrated last year in Guatemala. There, Guatemalan officials found their newly opened 50-bed facility near the border with Mexico overwhelmed, because Mexican immigration authorities deported so many Guatemalan children (8). While the ratio of boys to girls was about three to one, $80 \%$ of UIC are between the ages of 15 and 18 (3).

\section{In America}

Apprehended UIC face a complicated system of detention, care and processing. The United States is one of a very few countries that detains children. Most other countries adhere to the UNHCR guidelines, which suggest alternatives to detention, such as placing unaccompanied minors in a country's child welfare programs and granting them services equivalent to those provided its citizens (1). Detention, transfer and removal of children are the responsibility of DHS, while their care and custody falls to the ORR, part of the Department of Health and Human Services (HHS). For years, the Immigration and Naturalization Service (INS) was responsible for both, but in 2002, the Homeland Security Act transferred the care and custody of unaccompanied minors to ORR (1). The State Department and the Department of Justice also are key participants in processing these children. Appendix A shows the complex and intimidating world of the immigration and juvenile justice systems (9).Notwithstanding the difficulties and traumas associated with traveling alone, crossing borders and the risk of apprehension, UIC in the U.S. system face many other decisions and hardships. The first decision, usually made by the children without an attorney, is whether to stay or be repatriated (9). If they elect to stay, they could be transferred to a shelter far from family members. The next challenge is contacting the child's family, which can be difficult, not only because of their country of origin, but because family in the U.S. may not have legal status. Even though they are in complex immigration proceedings, UIC are not entitled to guardians, ad litem or to court- appointed legal representation (9). Since current U.S. law does not require the government to provide legal counsel, children often face legal decisions alone. About eighty percent of unaccompanied minors wade through the complex process of obtaining lawful residency, outlined above, without representation (1). Children who have access to family/guardians, will "avoid the experience of detention and the trauma of going through the immigration proceedings by themselves” (9).

\section{The role of Information Technology}

IT plays a crucial role in caring for UIC at many points, and in helping to empower this especially vulnerable group and their families. Prior to the era of email and the worldwide web, migrants had little or no communication with the families they left behind in their home country. However, in the era of cell phones and email, IT has created a new lifeline that links families as never before. Entrepreneurial businesses have recently sprouted, to provide videoconferencing between the US and a location in another country. This visual connection is comforting to both parties, especially the younger migrants. "Our goal is simple... we want husbands to see their wives. We want fathers to see their daughters. We want to bring families together," said Elias Chavando, President of TVO Communications, which set up public videoconferencing rooms (10).

\section{The web}

Transnational people have turned to the web to help them encounter or build community and identity. Organizations have developed sites that help the migrant community to understand laws and legal rights, to learn about different services, to keep in touch with news back home and to help migrants personally and collectively. There are many examples on the web of how transnational communities may be helped. A widely known and used site is NRI Online - Non Resident Indians Online (http://www.nriol.com). It describes itself as, "the premier web destination for Non Resident Indians (NRIs) worldwide...” (11). Other examples of sites that may help immigrant populations include Haiti Insight On-line (http://www.nchr.org/linkson_haiti.htm); the Asian American Justice Center (http://www.advancingequality.org/); and the National Council of la Raza (http://www.nclr.org/section/audience/media/me 
dia_guide). For a larger scope one may examine the pages of The National Network for Immigrant and Refugee Rights (http://www.nnirr.org/immigration/immigration services.html). Access to cyberspace is still an issue for hundreds of millions global citizens. However, "it is also the case that people in most nations are quickly beginning to leapfrog towards a greater presence in cyber space....Such rapid growth opens up questions of the role and effectivity of the internet in shaping current society” (12).

\section{Storytelling and identity}

The web certainly provides valuable information and links to communities. However, cyberspace could not only provide goods and services, but also help individuals and communities to shape themselves and their place in the world. The web can play a role in helping migrants tell others about themselves. Telling stories about oneself is an especially rich and powerful experience for a marginalized segment advised to keep quiet, or, for reasons for security, keeps quiet. "The internet presents the potential of seizing and realigning the cultural and speaking capital as well as the public sphere within which the speaking occur" (12). Instead of shame and silence, parents of UIC could find ways to help one another by way of information, but also by means of expressing themselves. "[I]t is possible to enter into a dialogue where the dominant cannot systematically drown out or silence the marginal” (12). The U.S. Committee for Refugees and Immigrants site (http://www.refugees.org) offers examples of how immigrant communities may express their story. For unaccompanied immigrant children The Posadas Project (Posada, 2007) is dedicated to helping spread their story.

IT can play a crucial role by helping UIC to tell their story to people whom they trust. These advocates can accompany the children and move their stories to the places of power and to people of influence. This process may take years, but IT is essential for global community members who defend children's rights, like Amnesty International or Human Rights Watch and for transnational actors like the United Nations, Doctors Across Borders, Amnesty International or religious institutions such as the Catholic, Episcopal or Lutheran Churches to help these groups aid in this process.

\section{IT and the Immediate Issues of Detention, Care and Custody}

IT is valuable in the operations and administration of each one of the many U.S. government organizations that have a variety of roles to play in dealing with UIC. ORR added many new responsibilities in its recently updated mission of caring for UIC, and it has assigned a high priority to the standardization of databases among federal agencies (Havens, 2007). It is also important for DHS and ORR to utilize the very experienced community of agencies that can help them care for this young population. Advocates often call for the government to recruit community-based programs to "provide staffing assistance that is child-friendly and culturally and linguistically appropriate" (9). Given the need to create information and constantly update and pass along new information to several organizations, IT's role is not only valuable, but it is integral to the care and custody of UIC. IT provides stakeholders with access to the scholarship and research on the global phenomenon of an increasing number of children crossing borders.

For a system full of children, most of whom do not have an attorney, the most pressing need for UIC is competent legal representation. A few of the key legal advocacy organizations that have formed networks are: the Immigrant Children Lawyers

Network (http://www.refugees.org/article.aspx?id=1680\& subm=75\&ssm=124\&area=Participate), National Immigration Law Center (http://www.nilc.org/), Catholic Legal Immigration Network (http://www.cliniclegal.org). The Midwest Immigrants \& Human Rights Center has a video library of streaming videos to help train attorneys and care providers. Pro Bono Partnerships

(http://www.probonopartnership.org/) is an example of a legal resource center for nonprofits. All these rely on networks, databases, list serves, links, conference calls and video conferencing. The effects of globalization may more easily toss people from one shore to another, but attorneys in the U.S. may be able to contact families, attorneys, service providers, or police in the home countries to help the cases of children.

Most families need remittances from migrants for mere subsistence. Economic hardship despite globalization is a major factor in migration, 
whether legal or illegal. Many of the countries from which the migrants come, have high unemployment, sometimes as high as 60 percent, according to local officials. Globalization has not reduced that figure, particularly in Latin and Central America. Remittances are crucial for small Central American countries, such as El Salvador, home to the Washington region's largest immigrant community. The more than $\$ 3.3$ billion that immigrants sent to their families last year makes up 18 percent of El Salvador's national income and surpasses foreign aid and investment, the Inter-American Dialogue study said. Most of the money goes to rural areas and helps raise families above the poverty line (13). The poor Central American families who receive remittances spend about 80 percent of the money on essentials, such as food, housing, and clothes, but the remaining 20 percent could be saved, if financial services were more readily available, he said. About 95 percent of remittance money is spent for consumption and services, and little of it converted to wealth (13).

The money-transfer market "from the United States to Latin America is based on pricing information gathered from 84 money transfer companies and in-depth interviews with executives of 22 financial institutions" (5). Western Union, which has numerous offices abroad, is one of the large organizations that transmit funds from the US to the migrant's home country. The recipient may collect the funds from one of those sites. Several other organizations provide that service. City National Bank of New Jersey transmits funds to Fonkoze's customers in Haiti for a flat fee (14), rather than charge a percentage of the transmitted amount as some transmitters do. However, the request for and the arrival of the funds in the home country, is not a minor matter. Many of the people in need of funds live in rural areas, where the infrastructure is inadequate for any electronic activity. In fact, many of these areas do not have electricity, and basic amenities and they have no convenient access to a telephone or the Internet. However, Grameen Foundation introduced an innovative concept to address this issue. The Grameen organization started as a microfinance institution (MFI), and they now loan money to entrepreneurs who buy a cell phone and allow neighbors to use it for a fee (15). Recently, Grameen collaborated with Fonkoze, an MFI in Haiti, to offer this service in Haiti.

\section{Education}

IT is in the forefront of delivering education. With the advent of the Internet and with the spreading wireless network access, rural areas benefit from educational modules or entire courses. The main hindrance is the paucity of educational material. It could take a significant amount of time to raise literacy rates in poor countries, where scarce resources and inadequate infrastructure prevent widespread access to the Internet. In Haiti and Nicaragua, both just a short distance from the US, $80 \%$ of the population lives below the poverty line (16), leaving almost no disposable income. Negroponte (17) created a project "One laptop Per Child" (OLPC) to market a laptop for under $\$ 200$ (with a handcrank to generate power). The design effort and innovative solutions that the project has already generated will continue to have an impact on mainstream computing for a few years (18).

\section{CONCLUSIONS}

There are many UIC in the US, who need caring adult supervision to navigate the dangerous waters of an unfamiliar country amidst confusing legal and bureaucratic regulations. This paper identified many resources that could be available to persons who provide care to the UICs. Failure to care for their needs could land the children in serious physical and legal trouble, at a significant cost to the US. Perhaps a central clearinghouse could result from this paper, so that using Web resources, anyone interested in information related to UICs would know where to find that service.

\section{REFERENCES}

1. Seugling, C., Toward a comprehensive response to the transnational migration of unaccompanied minors in the United States. Vanderbilt Journal of Transnational Law 37.3 (May 2004): p861(35).

2. Brusk, Alison, Children Across Borders: Patrimony, Property, or Persons?, p. 153 from People Out of Place; Globalization, Human Rights and the Citizenship Gap, Alison Brysk and Gershon Shafir, eds.; Routledge: Taylor \& Francis Group, New York, 2004.

3. Congressional Research Service (CRS): Report for Congress: Unaccompanied Immigrant Children: Policies and Issues; March 1, 2007. 
4. Weiss, J., "U.S. Department of Justice Immigration \& Naturalization Service, Guidelines for Children's Asylum Claims, n.10, (1998), available at www.ilw.com/bellU.S.C.io/childr .pdf.

5. Orozco, M., 2004, The Remittance Marketplace: Prices, Policy and Financial Institutions, Pew Hispanic Center Report, May 1, 2004.

6. Goodman, Peter S. "In Mexico, 'People Do Really Want to Stay'; Chicken Farmers Fear U.S. Exports Will Send More Workers North for Jobs" The Washington Post 7 Jan. 2007, Feature ed. Proquest.

7. Interview with Roberto Currie S.J., 5/9/2007.

8. Aizenman, N.C., "Young Migrants Risk All to Reach U.S.” Washington Post, August 28, 2006: A01.

9. National Juvenile Justice Network and National Collaboration for Youth, "Undocumented Immigrant Youth: Guide for Advocates and Service Providers; Policy Brief No. 2;” November 2006, appendix.

10. Business Wire, Sept 17, 1998, "Public Videoconferencing Rooms in California and Mexico Bring Families Together in Real Time”, Business Wire, Los Angeles Sept, 1998.

11. NRI Online is http://www.nriol.com/
12. Mitra, A., and Watts, E., "Theorizing cyberspace: the idea of voice applied to internet discourse," new Media \& Society, Vol. 4 (4) 2002; online at http://www.nms.sagepub.com/cgi/content/ab stract/4/4/479, p. 480.

13. Williams, K, 2007, Immigrants Slow Rate Of Money Transfers; Remittances Crucial to Poor Nations, Washington Post, May 1, 2007.

14. Fonkoze, 2007, http://www.fonkoze.org/sendmoney.htm.

15. Grameen Telecom, 2007, http://www.grameeninfo.org/grameen/gtelecom/Markoff, J., \$100 Laptop, NY Times, January 29, 2007.

16. CIA, World Factbook - Mexico, 2007, www.cia.gov/library/publications/the-worldfactbook/index.html.Fussel, E., and Massey D., 2004, The Limits to Cumulative Causation: International Migration from Mexican Urban Areas., Demography, Washington, Feb, 2004, V41, 1 p151.

17. Levy, S., 2007, Can $\$ 100$ Laptop Change the World?, Newsweek, NY, Feb 19, 2007, Iss 7, p 12.

18. Markoff, J., 2007, \$100 Laptop, NY Times, January

29 ,

2007. 
IMMIGR.ANT YOUTH GET INVOLVE WITH THE IMMIGRATION AND JUVENILE JUSTICE SYSTEM ${ }^{2}$

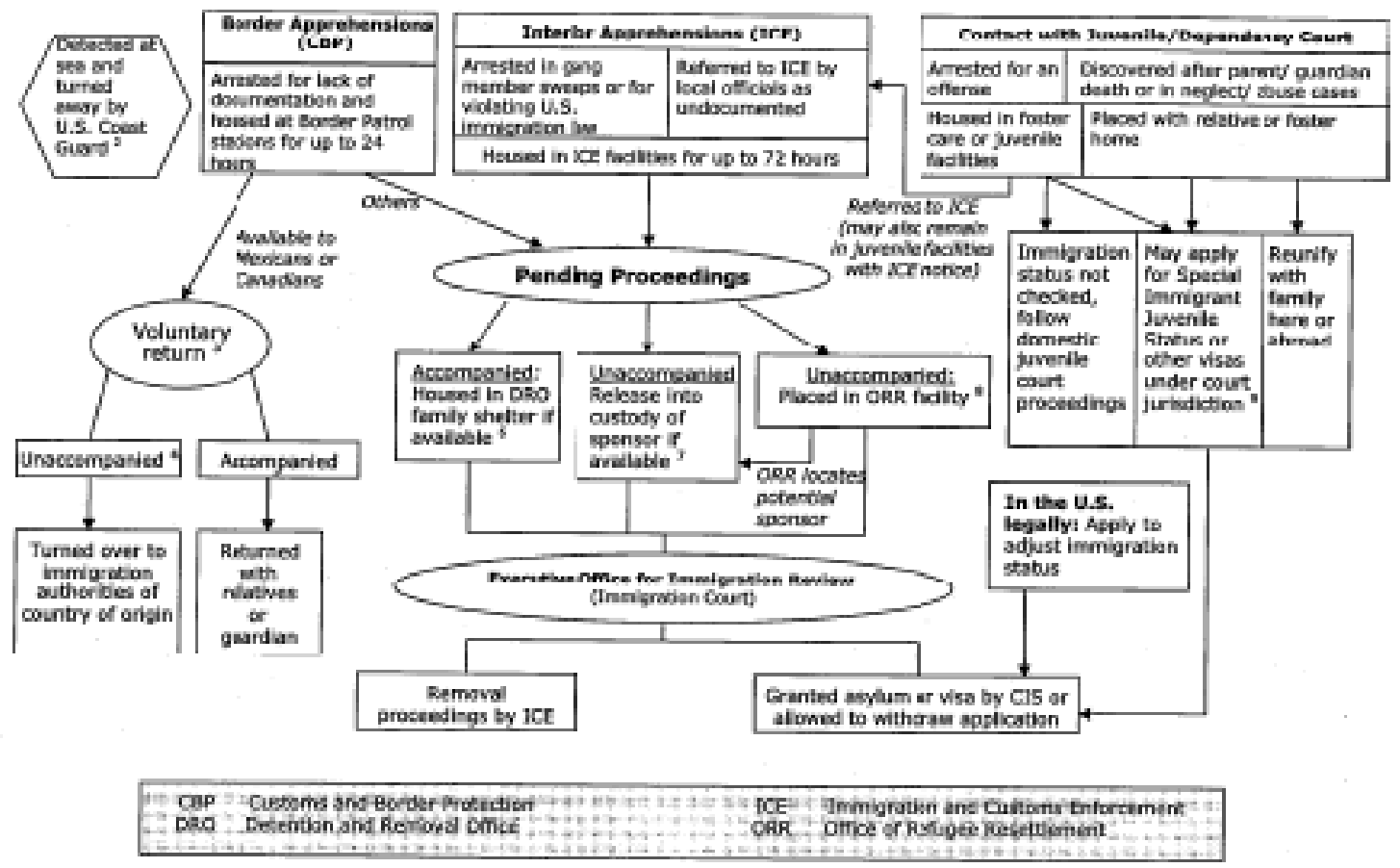

Appendix $A$ 